\title{
Maize leaf development under climate change scenarios
}

\author{
Nereu Augusto Streck(1), Josana Andréia Langner ${ }^{(1)}$ and Isabel Lago ${ }^{(1)}$ \\ (1)Universidade Federal de Santa Maria, Departamento de Fitotecnia, Avenida Roraima o 1.000, Bairro Camobi, CEP 97105-900 Santa Maria, RS. \\ E-mail: nstreck2@yahoo.com.br, josana.langner@yahoo.com.br, isalago08@yahoo.com.br.
}

\begin{abstract}
The objective of this work was to simulate maize leaf development in climate change scenarios at Santa Maria, RS, Brazil, considering symmetric and asymmetric increases in air temperature. The model of Wang \& Engel for leaf appearance rate (LAR), with genotype-specific coefficients for the maize variety BRS Missões, was used to simulate tip and expanded leaf accumulated number from emergence to flag leaf appearance and expansion, for nine emergence dates from August 15 to April 15. LAR model was run for each emergence date in 100-year climate scenarios: current climate, and $+1,+2,+3,+4$ and $+5^{\circ} \mathrm{C}$ increase in mean air temperature, with symmetric and asymmetric increase in daily minimum and maximum air temperature. Maize crop failure due to frost decreased in elevated temperature scenarios, in the very early and very late emergence dates, indicating a lengthening in the maize growing season in warmer climates. The leaf development period in maize was shorter in elevated temperature scenarios, with greater shortening in asymmetric temperature increases, indicating that warmer nights accelerate vegetative development in maize.
\end{abstract}

Index terms: Zea mays, elevated temperature, frost risk, global warming, leaf appearance, vegetative development.

\section{Desenvolvimento foliar de milho em cenários de mudanças climáticas}

Resumo - O objetivo deste trabalho foi simular o desenvolvimento foliar de milho em cenários de mudanças climáticas, em Santa Maria, RS, Brasil, considerando-se aumentos simétricos e assimétricos na temperatura do ar. O modelo de Wang \& Engel para a taxa de aparecimento de folhas, com coeficientes específicos de genótipos para a variedade milho BRS Missões, foi usado para simular o número acumulado de folhas total e de folhas expandidas, da emergência até o aparecimento e expansão da folha bandeira, em nove datas de emergência, de 15 de Agosto a 15 de Abril. O aparecimento de folhas foi simulado para cada data de emergência, nos seguintes cenários climáticos de cem anos: clima atual e com aumento de $+1,+2,+3,+4 \mathrm{e}+5^{\circ} \mathrm{C}$ na temperatura média do ar, com aumento simétrico e assimétrico nas temperaturas mínima e máxima diária do ar. O insucesso do cultivo de milho em razão da geada, diminuiu em cenários de temperatura elevada, nas datas de emergência muito cedo e muito tarde, o que indica aumento na estação de cultivo de milho em climas mais quentes. O período de desenvolvimento foliar de milho foi mais curto em cenários de temperatura elevada, com maior encurtamento em aumentos assimétricos da temperatura, indício de que noites mais quentes aceleram o desenvolvimento vegetativo em milho.

Termos para indexação: Zea mays, temperaturas elevadas, risco de geada, aquecimento global, aparecimento de folhas, desenvolvimento vegetativo.

\section{Introduction}

Maize (Zea mays L.) is a C4 plant and a major grain crop worldwide. It constituted a main staple food for ancient pre-hispanic cultures of South American Andes civilizations, and had its cultivation expanded to all continents. Maize is a major ingredient for feeding animals in poultry, swine, and cattle ranches. In addition to its use as human and animal food, maize is also a potential crop for ethanol. World production in 2009 was about 808 million megagrams, and Brazil is a major producer with 53 million megagrams produced in this year (United States Department of Agriculture, 2010).

Leaf development, represented by the appearance and accumulation of leaves, is an important part of the vegetative development of agricultural crops. In maize, leaf development starts at emergence and ends with the appearance and expansion of the flag leaf, when the final leaf number (FLN) is defined. In this crop, vegetative development overlaps the reproductive one. Therefore, leaf number (LN) is related to some reproductive developmental stages, 
such as ears and tassel initiation (Forsthofer et al., 2004). As LN increases, crop leaf area index (LAI) for photosynthesis and crop biomass production also increases. Nitrogen dressing in maize is also related to $\mathrm{LN}$, being recommended at V4 (four expanded leaves), V7 (seven expanded leaves), and V11 (eleven expanded leaves) (Forsthofer et al., 2004). Thus, any management practice or biotic and abiotic stresses that affect leaf development may potentially impact reproductive growth and development, and ultimately impact crop yield.

There is an increasingly consensus among scientists that climate is changing and may continue to change by the end of this century. If natural, anthropogenic or both causes are responsible for the climate change is still under debate (Mann et al., 1998, 1999, 2008; Intergovernmental Panel on Climate Change, 2007; Molion, 2009). One of the signals of climate change is the rising of near-surface air temperature due to increasing greenhouse gases concentration. According to the fourth report of the Intergovernmental Panel on Climate Change (Intergovernmental Panel on Climate Change, 2007), global air temperature over the continents and over the oceans is increasing, and snow cover is decreasing. During the XX century, global mean surface air temperature has increased $0.6 \pm 0.2^{\circ} \mathrm{C}$, with the 90 's being the hottest decade in the last millennium (Kerr, 2005; Intergovernmental Panel on Climate Change, 2007; Mann et al., 1998, 1999). Also according to the Intergovernmental Panel on Climate Change (2007), rising temperature during the past century extends to South America and Brazil.

A particular feature of global warming is that the increase in air temperature in some locations has been asymmetric, with greater increase in minimum than in maximum daily air temperature (Peng et al., 2004). Some locations in Rio Grande do Sul state, such as Pelotas, showed this warming pattern (Marques et al., 2005; Steinmetz et al., 2005). For the decades ahead, projections by the Intergovernmental Panel on Climate Change (2007) are for increases of $1.1^{\circ} \mathrm{C}$ to $6.4^{\circ} \mathrm{C}$ in mean air temperature by the end of this century, in several locations including in Brazil.

A major challenge for future generations is to keep competitiveness and sustainability in agriculture as food demand increases. In order to cope with agriculture challenges in the future, it is important to address crop responses to climate change (Travasso et al., 2009) and to understand how basic plant processes will be affected by climate change scenarios (Kim et al., 2007). Among such processes, leaf development plays an important role in crop performance in a changing climate. However, assessing the impact of climate change on leaf development has not been done for maize in Brazilian conditions.

The objective of this study was to simulate leaf development of maize in climate change scenarios at Santa Maria, RS, Brazil, considering symmetric and asymmetric increases in daily minimum and maximum air temperatures.

\section{Materials and Methods}

This numerical study was performed for Santa Maria, Brazil (29 $43^{\prime} \mathrm{S}, 53^{\circ} 43^{\prime} \mathrm{W}$, and $95 \mathrm{~m}$ altitude), located in the central region of Rio Grande do Sul state. This location has a normal monthly air temperature varying from 12.9 to $24.6^{\circ} \mathrm{C}$, and its total annual precipitation is $1,686 \mathrm{~mm}$. The cultivar BRS Missões, a synthetic maize variety developed by Embrapa Trigo was used in this work; it is recommended for cultivation in small farms in Rio Grande do Sul, Santa Catarina and Paraná states (Embrapa Trigo, 2005).

Leaf appearance rate (LAR) was simulated with Wang \& Engel (1998) model:

$$
\text { LAR }=\text { LARmax } \mathrm{f}(\mathrm{T})
$$

in which: LAR is the daily leaf appearance rate (leaves per day); LARmax is the maximum daily leaf appearance rate (leaves per day) at the optimum temperature; and $\mathrm{f}(\mathrm{T})$ is the temperature response function for LAR. The $\mathrm{f}(\mathrm{T})$ was calculated with the beta function:

$f(T)=\left[2\left(T_{-} T_{\text {min }}\right)^{\Delta}\left(T_{\text {opt }}-T_{\text {min }}\right)^{\Delta}-\left(T-T_{\min }\right)^{2 \Delta}\right] /\left(T_{\text {opt }}-T_{\text {min }}\right)^{2 \Delta}$

for $T \min \leq \mathrm{T} \leq \mathrm{T} \max$ and $\mathrm{f}(\mathrm{T})=0$ for $\mathrm{T}<\mathrm{T} \min$ or $\mathrm{T}>\mathrm{T} \max (2)$

$\Delta=\ln 2 / \ln \left[\left(\mathrm{T}_{\max }-\mathrm{T}_{\min }\right) /\left(\mathrm{T}_{\mathrm{opt}}-\mathrm{T}_{\min }\right)\right]$ 
in which: Tmin, Topt and $T_{\max }$ are the cardinal minimum, optimum, and maximum, respectively, temperatures for LAR; and T is the daily minimum (TM) or maximum (TX) air temperature.

The accumulated leaf number (LN) was calculated starting at crop emergence by accumulating LAR as $\mathrm{LN}=\Sigma \mathrm{LAR}$. Leaf appearance rate was calculated on leaf tip (LNtip) and on expanded leaf (LNexp) basis. A leaf was assumed expanded when ligule is visible (Streck et al., 2009). Values of LARmax for the variety BRS Missões were 0.626 and 0.452 leaves per day for tip and expanded leaves, respectively; and cardinal temperatures for both tip and expanded LAR were: Tmin, $8{ }^{\circ} \mathrm{C}$; Topt, $31^{\circ} \mathrm{C}$; and $\mathrm{T}_{\max }, 41^{\circ} \mathrm{C}$ (Streck et al., 2009). The $\mathrm{f}(\mathrm{T})$ was calculated daily for TM and for TX and then averaged (Streck et al., 2009).

Nine sowing dates were considered in the simulations, resulting in the following crop emergence dates (month/day): 08/15, 09/15, 10/15, $11 / 15,12 / 15,01 / 15,02 / 15,03 / 15$, and $04 / 15$. LAR calculations started at the emergence day and ended when the flag leaf has emerged (FLNtip) or expanded (FLNexp). For this variety, the flag leaf number (FLN) was assumed as the sowing date dependent, based on records from field experiments during two growing seasons (2006/07 and 2007/08) with several sowing dates at Santa Maria, RS (Streck et al., 2009). The number of leaves for FLN, for each emergence date, was: $08 / 15,21 ; 09 / 15,21$; $10 / 15,21 ; 11 / 15,22 ; 12 / 15,22 ; 01 / 15,21 ; 02 / 15$, 20; 03/15, 20; and 04/15, 19 leaves. This wide range of emergence dates was used to simulate leaf development considering crop sown before, during, and after the currently recommended period for sowing maize in this location, which is from 08/11 to $01 / 20$ (Reunião Técnica Annual do Milho, 2008).

Climate change scenarios were 100 years of current climate and with increased mean air temperature of $+1,+2,+3,+4$, and $+5^{\circ} \mathrm{C}$, with symmetric and asymmetric increases in minimum and maximum daily temperature, totaling eleven climate scenarios. For the asymmetric scenarios, the increase in daily minimum temperature was $20 \%$ greater than for daily maximum temperature (Lago et al., 2008). These climate change scenarios are synthetic time series created with the LARS-WG weather generator (Semenov et al., 1998), using a 1969-2003 data base of daily minimum and maximum air temperature measured at a conventional meteorological station in Santa Maria, RS. These 100-year daily time series have been previously tested and are suitable for using in climate change studies (Streck \& Alberto, 2006a, 2006b; Streck et al., 2006; Lago et al., 2008).

The LAR model (equation 1) for both tip and expanded LN was run for each of the eleven climate scenarios and for each of the nine emergence dates. Because emergence dates in August, March, and April correspond to sowings out of the recommended season in this location under current climate $(08 / 11$ to $01 / 20$ ), it was assumed that if Tmin was lower than or equal to $3^{\circ} \mathrm{C}$, canopy temperature would reach the lower threshold temperature of $-2^{\circ} \mathrm{C}$, and crop would fail by frost due to tissue chilling and intercellular and intracellular freezing injury (Levitt, 1972). The assumption of a lower threshold temperature of $3{ }^{\circ} \mathrm{C}$ for frost was based on results obtained by Heldwein et al. (1988), in which minimum air temperature over short grass is at least $5^{\circ} \mathrm{C}$ lower than minimum air temperature inside the meteorological shelter, in Santa Maria. No crop failure due to high temperature was considered in this study because it was assumed an irrigated maize cultivation (Streck et al., 2009). According to Gardner et al. (1981), irrigated maize crops canopy temperature is $1-2^{\circ} \mathrm{C}$ lower than air temperature (sunlit leaves at midday) in nonstressed maize plants because of transpiration. As upper lethal temperature for maize is $49-51{ }^{\circ} \mathrm{C}$ (Levitt, 1972), and $T_{\max }$ reached a maximum temperature of $49.7^{\circ} \mathrm{C}$ in the climate scenarios, this assumption is acceptable. In addition, damage by heat is much more difficult to quantify than by freezing, since at upper lethal temperature there is no change in water phase as it occurs with lower lethal temperatures, when irreversible damage occurs caused by freezing of cell water (Levitt, 1972).

Variables of interest were: the number of years, in which crop would fail due to frost in each climate scenarios; crop emergence to flag leaf emergence (EM-FLem); and crop emergence to flag leaf expansion (EM-FLexp) periods (days). Mean and standard deviation of EM-FLem and EM-FLexp were calculated for each of the evaluated scenarios. Analysis of variance was performed for these variables considering a 9x11 factorial experiment (emergence dates $\mathrm{x}$ climate scenarios). EM-FLexp 
and EM-FLem means were compared by Tukey test, at $5 \%$ probability. In addition, the date of V4, V7, and V11 developmental stages, when nitrogen dressings are recommended for maize (Forsthofer et al., 2004), was also estimated. These developmental stages are based on expanded LN at V4, V7, and V11 and the $\mathrm{LN}_{\exp }$ is 4, 7, and 11 leaves, respectively (Ritchie et al., 1997).

\section{Results and Discussion}

In the 100 years of each climate scenarios there were 99 growing seasons because a summer crop, like maize, grown in the Southern Hemisphere is sown in the second semester of the year, and its developmental cycle extends to the first semester of the upcoming year. Under current climate scenario, maize crop emerged on $08 / 15,03 / 15$, and $04 / 15$ was simulated to fail due to frost before the flag leaf expansion in 65,85 , and 99 out of the 99 growing seasons, respectively (Table 1). Therefore, these emergence dates are out of the currently recommended sowing dates for maize in this subtropical location.

For the other six emergence dates under current climate, the $09 / 15$ emergence date had 23 years of simulated crop failure due to frost, the $10 / 15$ sowing date had one year, and the 02/15 emergence date had nine years, out of 99 growing seasons (Table 1), which indicates that early sowing dates in September, within the currently recommended sowing period, have some risks, which is also realistic as recently reported by the state extension service (during the Spring 2009), many maize fields were heavily damaged by frosts in September in Santa Maria county.

As temperature increased in the climate scenarios, the number of years in which crop would fail due to frost decreased for the early and late emergence dates (Table 1). For the symmetric scenarios, the reduction in the number of years with crop losses due to frosts, from the current to the $+5^{\circ} \mathrm{C}$ climate scenario, was 58 years (from 65 to 7 years), 16 years (from 16 to zero year), and 88 years (from 90 to 2 years) in the $08 / 15$, $03 / 15$, and $04 / 15$ emergence dates, respectively. In the symmetric scenarios this reduction was 58 years (from 65 to 7 years), 84 years (from 85 to one year), and 82 years (from 99 to 17 years), respectively. These results indicate that, if global warming takes place, compared to the current climate, the growing season for maize in Santa Maria will be longer by the end of this century, i.e. anticipated in the winter and expanded into late summer. A lengthening in the calendar for growing crops may lead to profound changes in field management practices, such as crop rotation schedules, and pest and disease occurrences, which can be beneficial on one hand - allowing of more than one maize cropping per year -, but of high concern on the other hand, considering that many insects and pathogens may survive during winter time, thus increasing risks and costs with sprayings for the upcoming growing season.

The duration of the EM-FLem and EM-FLexp periods in the climate scenarios is plotted in Figures 1 and 2, respectively. Analysis of variance indicated significant main effects and interaction between emergence date and climate scenarios for both

Tabela 1. Number of years out of 99 growing seasons in which maize crop variety BRS Missões was simulated to fail due to frost, according to different emergence dates and climate scenarios, in Santa Maria, RS, Brazil.

\begin{tabular}{|c|c|c|c|c|c|c|c|c|c|c|c|}
\hline \multirow[t]{3}{*}{ Emergence date } & \multicolumn{11}{|c|}{ Climate scenarios $^{(1)}$} \\
\hline & \multirow[t]{2}{*}{ Current } & \multicolumn{2}{|c|}{$+1^{\circ} \mathrm{C}$} & \multicolumn{2}{|c|}{$+2^{\circ} \mathrm{C}$} & \multicolumn{2}{|c|}{$+3^{\circ} \mathrm{C}$} & \multicolumn{2}{|c|}{$+4^{\circ} \mathrm{C}$} & \multicolumn{2}{|c|}{$+5^{\circ} \mathrm{C}$} \\
\hline & & $\mathrm{Sy}^{(2)}$ & $\mathrm{Asy}^{(3)}$ & Sy & Asy & Sy & Asy & Sy & Asy & Sy & Asy \\
\hline $08 / 15$ & $65(65)$ & $53(53)$ & $52(52)$ & $41(41)$ & $39(39)$ & $31(31)$ & $23(23)$ & $18(18)$ & $12(12)$ & 11(11) & $7(7)$ \\
\hline $09 / 15$ & $23(23)$ & $13(13)$ & $13(13)$ & $9(9)$ & $8(8)$ & $7(7)$ & $4(4)$ & $3(3)$ & $3(3)$ & $3(3)$ & 1(1) \\
\hline $10 / 15$ & $1(1)$ & $0(0)$ & $0(0)$ & $0(0)$ & $0(0)$ & $0(0)$ & $0(0)$ & $0(0)$ & $0(0)$ & $0(0)$ & $0(0)$ \\
\hline $11 / 15$ & $0(0)$ & $0(0)$ & $0(0)$ & $0(0)$ & $0(0)$ & $0(0)$ & $0(0)$ & $0(0)$ & $0(0)$ & $0(0)$ & $0(0)$ \\
\hline $12 / 15$ & $0(0)$ & $0(0)$ & $0(0)$ & $0(0)$ & $0(0)$ & $0(0)$ & $0(0)$ & $0(0)$ & $0(0)$ & $0(0)$ & $0(0)$ \\
\hline $01 / 15$ & $0(0)$ & $0(0)$ & $0(0)$ & $0(0)$ & $0(0)$ & $0(0)$ & $0(0)$ & $0(0)$ & $0(0)$ & $0(0)$ & $0(0)$ \\
\hline $02 / 15$ & $0(9)$ & $0(4)$ & $0(3)$ & $0(2)$ & $0(1)$ & $0(0)$ & $0(0)$ & $0(0)$ & $0(0)$ & $0(0)$ & $0(0)$ \\
\hline $03 / 15$ & $16(85)$ & $9(60)$ & $8(59)$ & $3(34)$ & $1(30)$ & $1(13)$ & $1(7)$ & $0(3)$ & $0(2)$ & $0(2)$ & $0(1)$ \\
\hline $04 / 15$ & $90(99)$ & $69(97)$ & $67(97)$ & $52(88)$ & $47(85)$ & $30(75)$ & $23(66)$ & $13(52)$ & $9(40)$ & $6(30)$ & $2(17)$ \\
\hline
\end{tabular}

${ }^{(1)}$ Values off parenthesis correspond to the years in which crop was killed considering tip leaf number, and values inside parenthesis correspond to the same variable but considering expanded leaf number. ${ }^{(2)}$ Symmetric increase in daily minimum and maximum air temperature. ${ }^{(3)}$ Asymmetric increase in daily minimum and maximum air temperature. 
EM-FLem and EM-FLexp variables. In regard of main effects, mean square was larger for emergence date than for climate scenarios, suggesting that the time of crop emergence has a larger effect on leaf development than climate scenarios. The high effect of emergence date is important to address, in different sowing times, what would happen if climate changes.

Among emergence dates, for each climate scenario, the duration of both periods was the lowest in the $12 / 15$ and $01 / 15$ emergence dates, and the longest was in the very early $(08 / 15)$ and very late
(04/15) emergence dates. Among climate scenarios, the longest periods were under current climate and decreased as temperature increased, with greater effect of elevated temperature in the early $(08 / 15$ and $09 / 15)$ and late $(03 / 15$ and $04 / 15)$ emergence dates (Figures 1 A, B, H, I, and 2 A, B, H, I).

Considering the symmetric and asymmetric increases in air temperature scenarios, there was no difference in the duration of the periods for the $+1{ }^{\circ} \mathrm{C}$ scenario in all emergence dates. For greater increase in temperature scenarios, the duration of the periods was usually lower in the asymmetric
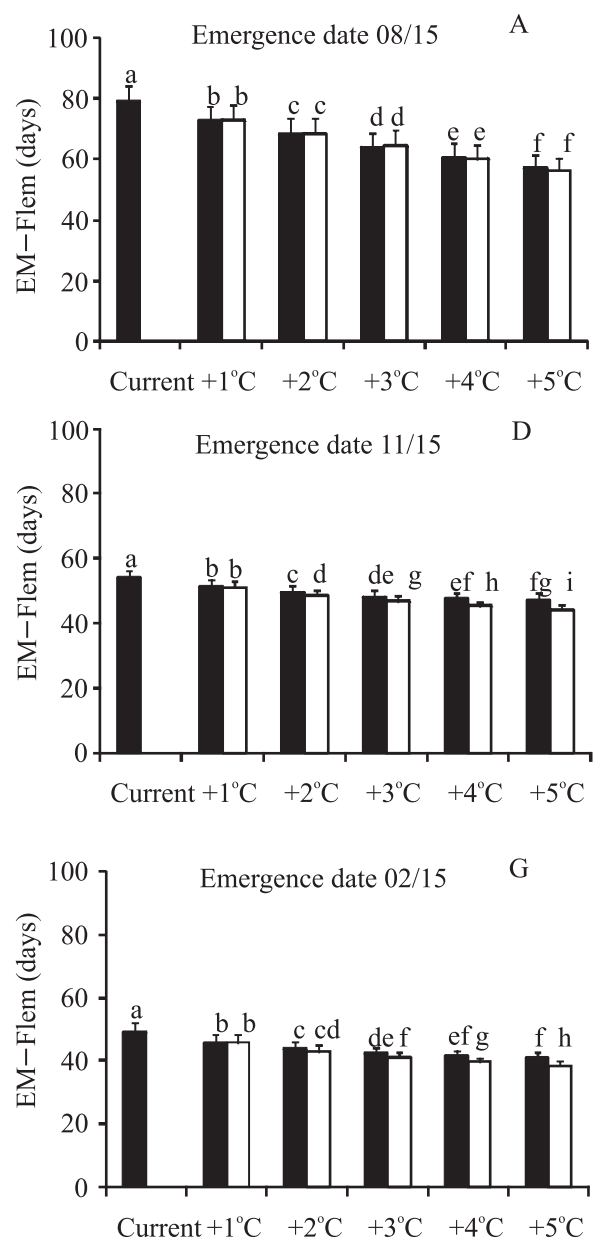

Climate scenarios
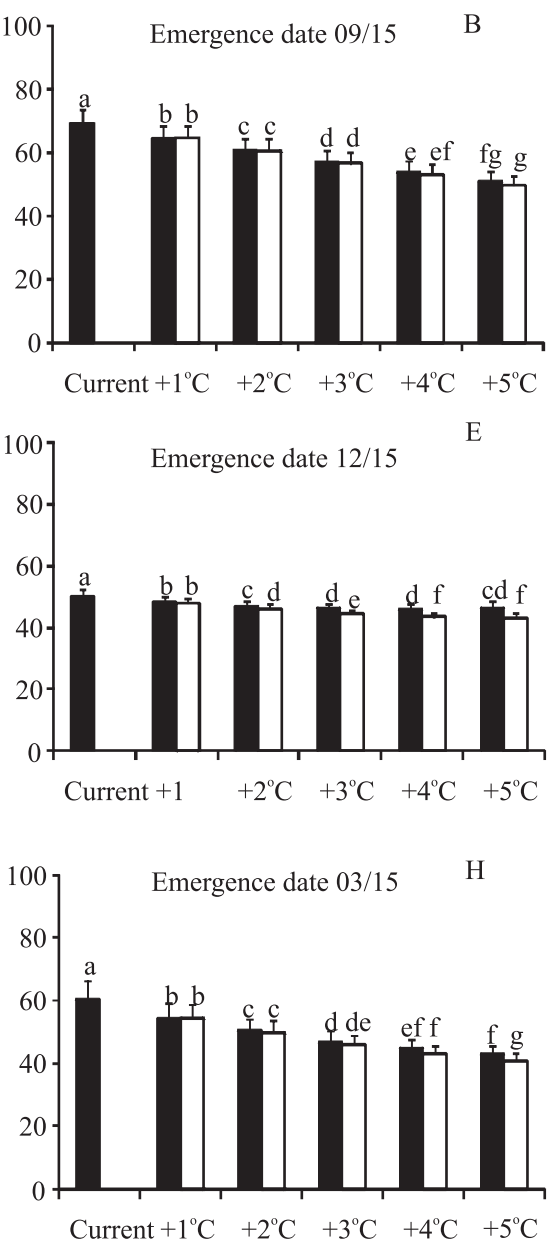

Climate scenarios

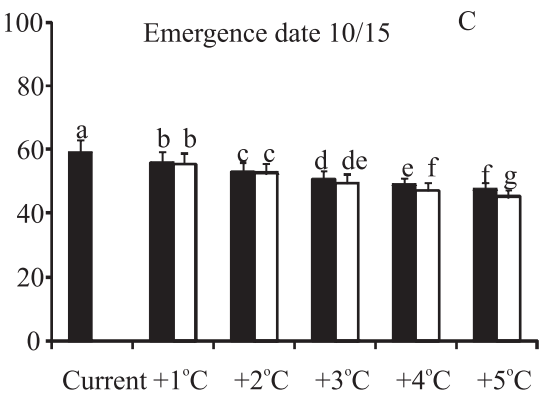

F
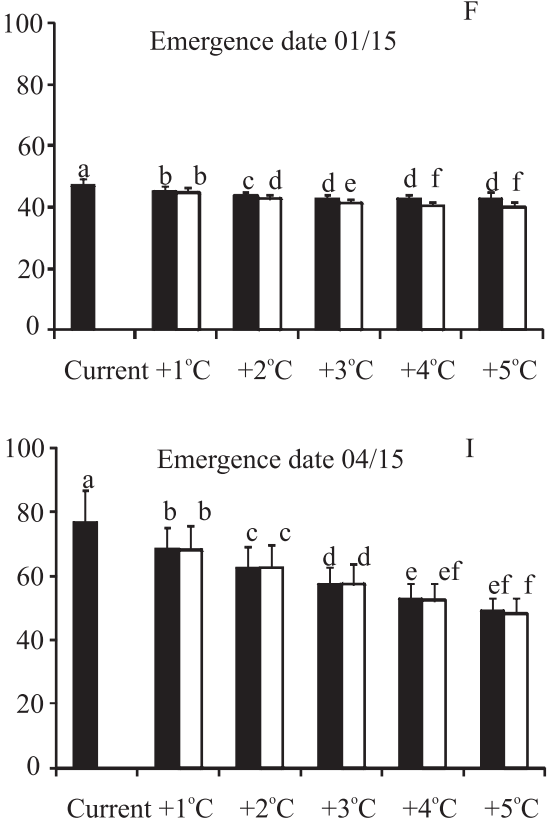

Climate scenarios

Symmetric $\square$ Asymmetric

Figure 1. Duration (days) of the emergence to flag leaf emergence (EM-FLem) period of maize variety BRS Missões, simulated for nine emergence dates, and climate scenarios with symmetric and asymmetric increases in daily minimum and maximum air temperatures, in Santa Maria, RS, Brazil. Each column is the mean of 100 years (99 growing season) of simulations, and error bars represent one standard deviation from the mean. Bars linked by the equal letters in each panel are not different, according to Tukey test, at $5 \%$ probability. 
scenarios, except for $08 / 15$ and $04 / 15$ emergence dates, when there was no difference (Figure $1 \mathrm{~A}, \mathrm{I}$, and $2 \mathrm{~A}, \mathrm{I})$. These results indicate that warmer nights (asymmetric scenarios) have a greater potential to hasten vegetative development of maize than cooler nights (symmetric scenarios) in this location. A shorter vegetative period and warmer nights may decrease the accumulation of photosyntates in the culm and can affect grain filling because of increased respiration rates, which may decrease reproductive growth and kernel yield in maize, as has been reported with rice (Peng et al., 2004).
This hypothesis constitutes a background for maize breeding programs to include resistance to high temperature in their portfolio of traits for future maize genotypes.

In Figure 3, plots with the simulated LNtip and LNexp as a function of days after emergence, in the two extreme scenarios (current and $+5^{\circ} \mathrm{C}$ symmetric), illustrate the dynamics of leaf development in the nine emergence dates. Firstly, the difference between LNtip and LNexp increases as time progresses, i.e. the number of unexpanded leaves at the whorl increases until flag leaf emergence, which is the result of
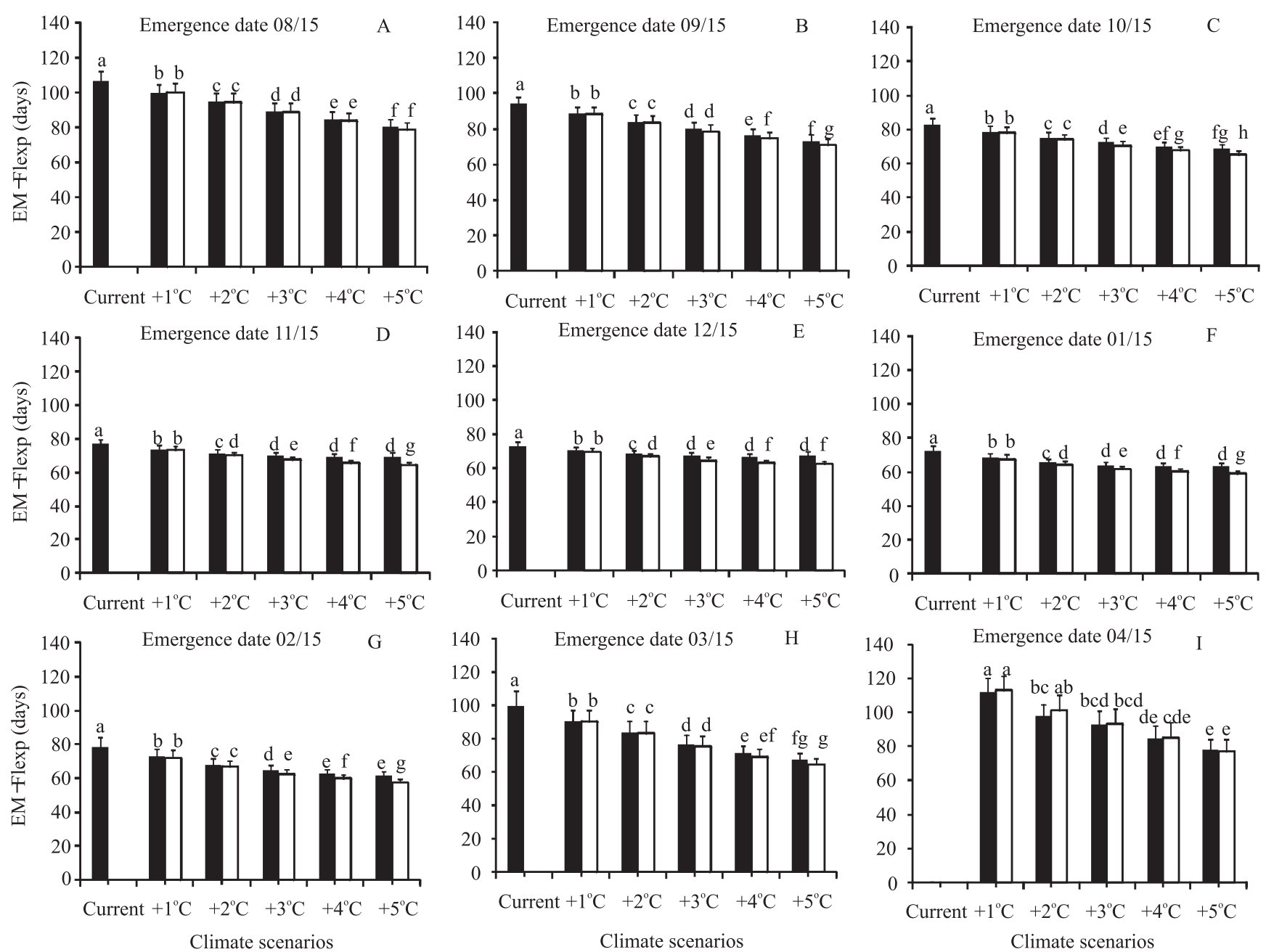

- Symmetric $\square$ Asymmetric

Figure 2. Duration (days) of the emergence to flag leaf expansion (EM-FLexp) period of maize variety BRS Missões, simulated for nine emergence dates, and climate scenarios with symmetric and asymmetric increases in daily minimum and maximum air temperatures in Santa Maria, RS, Brazil. Each column is the mean of 100 years (99 growing season) of simulations, and error bars represent one standard deviation from the mean. Bars linked by the equal letters in each panel are not different, according to Tukey test, at $5 \%$ probability. 
greater LARmax for tip (0.626 leaves per day) than for expanded (0.452 leaves per day) leaf number. Secondly, the increase in LN is much higher at elevated temperatures scenarios compared to current climate, especially in the early (08/15 and 09/15) and late $(03 / 15$ and $04 / 15)$ emergence dates. Thirdly, for current climate, the trend of data points curves up for early (spring) emergence dates $(08 / 15,09 / 15$, and 10/15), matches a straight line for intermediate (summer) emergence dates $(11 / 15,12 / 15$, and $01 / 15)$, and curves down for late (fall) emergence dates $(02 / 15,03 / 15,04 / 15)$, reflecting the increase and the decrease in daily air temperature as time progresses during the spring and during the fall of a mid-latitude subtropical location, respectively. These ups and downs in LN curves in opposite seasons are much less evident in the elevated temperature scenarios (Figure 3 A, B, C, G, H, I), indicating considerable changes in the leaf development dynamics in maize, if global warming is confirmed.

The shortening of leaf development period in maize, at elevated temperatures scenarios obtained in this study, agrees with results by Lago et al. (2008), who also simulated a decrease in the duration of
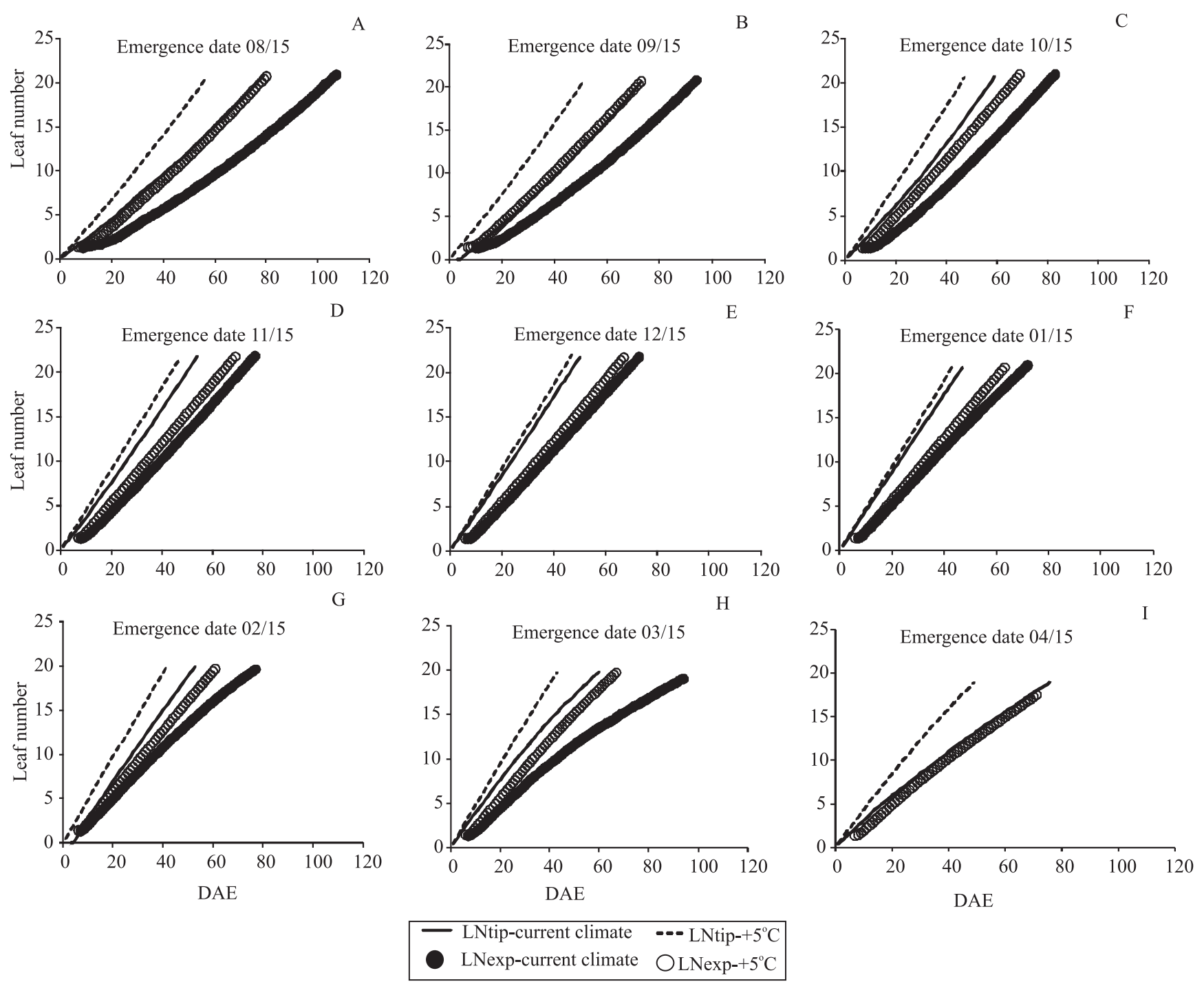

Figure 3. Accumulated tip leaf number (LNtip) and expanded leaf number (LNexp) of maize variety BRS Missões, as a function of days after crop emergence (DAE) until flag leaf appearance and flag leaf expansion, respectively, simulated in nine emergence dates for current climate and for the climate scenario of $+5^{\circ} \mathrm{C}$ with symmetric increase in daily minimum and maximum air temperatures, in Santa Maria, RS, Brazil. Data points are mean of 100 years (99 growing seasons) of simulations. 
the vegetative period (from crop emergence to panicle initiation) in rice in warmer climate scenarios. However, for potato, Streck et al. (2006) reported a lengthening of the vegetative periods (from crop emergence to tuber initiation) in warmer climate scenarios. The greater shortening of leaf development periods in maize, in the asymmetric compared to the symmetric increase temperature scenarios, also agrees with Lago et al. (2008), who reported shorter duration of the vegetative period in rice. One of the uncertainties for projected future climates is if minimum and maximum temperatures will rise at the same rate or not. However, if trends of greater increase in minimum than in maximum air temperature will extend to the future, as so far observed for some locations in Rio Grande do Sul state by Marques et al. (2005) and Steinmetz et al. (2005), then leaf development of maize may also respond differently, confirming the high vulnerability of agroecosystems to climate change (Intergovernmental Panel on Climate Change, 2007), as reported for maize in Africa and Latin America (Jones \& Thornton, 2003) and in India (Byjesh et al., 2010).

One field management practice in maize farms that is based on leaf development is nitrogen dressing, which is recommended at the V4, V7 and V11 phenological stages (Forsthofer et al., 2004). The effect of elevated temperature scenarios on these stage periods is shown in Table 2. As temperature increased, the date of the developmental stages is anticipated, mainly

Table 2. Simulated date for V4, V7 and V11 phenological stages of maize variety BRS Missões, in the current climate scenario, and deviation of the date (days) of these stages, according to climate change scenarios with symmetric (Sy) and asymmetric (Asy) increases in temperature.

\begin{tabular}{|c|c|c|c|c|c|c|c|c|c|c|c|}
\hline \multirow[t]{3}{*}{ Emergence date } & \multicolumn{11}{|c|}{ Climate scenarios $^{(1)}$} \\
\hline & \multirow[t]{2}{*}{ Current } & \multicolumn{2}{|c|}{$+1^{\circ} \mathrm{C}$} & \multicolumn{2}{|c|}{$+2^{\circ} \mathrm{C}$} & \multicolumn{2}{|c|}{$+3^{\circ} \mathrm{C}$} & \multicolumn{2}{|c|}{$+4^{\circ} \mathrm{C}$} & \multicolumn{2}{|c|}{$+5^{\circ} \mathrm{C}$} \\
\hline & & $\mathrm{Sy}^{(2)}$ & Asy $^{(3)}$ & Sy & Asy & Sy & Asy & Sy & Asy & Sy & Asy \\
\hline & \multicolumn{11}{|c|}{ V4 development stage } \\
\hline $08 / 15$ & $15 / 09(5)$ & $-3(4)$ & $-3(4)$ & $-5(4)$ & $-5(4)$ & $-7(3)$ & $-6(4)$ & $-8(3)$ & $-8(4)$ & $-10(3)$ & $-10(3)$ \\
\hline $09 / 15$ & $13 / 10(3)$ & $-3(3)$ & $-3(3)$ & $-5(3)$ & $-5(3)$ & $-6(3)$ & $-6(3)$ & $-8(2)$ & $-8(3)$ & $-9(2)$ & $-10(2)$ \\
\hline $10 / 15$ & 07/11(3) & $-2(3)$ & $-2(3)$ & $-3(2)$ & $-3(2)$ & $-4(2)$ & $-5(2)$ & $-6(2)$ & $-6(2)$ & $-6(1)$ & $-7(1)$ \\
\hline $11 / 15$ & $04 / 12(2)$ & $-1(2)$ & $-1(2)$ & $-2(1)$ & $-2(1)$ & $-3(1)$ & $-3(1)$ & $-3(1)$ & $-4(1)$ & $-4(1)$ & $-4(1)$ \\
\hline $12 / 15$ & 01/01(1) & $-1(1)$ & $-1(1)$ & $-2(1)$ & $-2(1)$ & $-2(1)$ & $-2(1)$ & $-2(1)$ & $-3(1)$ & $-2(1)$ & $-3(1)$ \\
\hline $01 / 15$ & $31 / 01(1)$ & $-1(1)$ & $-1(1)$ & $-1(1)$ & $-2(1)$ & $-1(1)$ & $-2(1)$ & $-1(1)$ & $-2(1)$ & $-1(1)$ & $-2(1)$ \\
\hline $02 / 15$ & 03/03(1) & $-1(1)$ & $-1(1)$ & $-1(1)$ & $-2(1)$ & $-2(1)$ & $-2(1)$ & $-2(1)$ & $-2(1)$ & $-2(1)$ & $-3(1)$ \\
\hline 03/15 & $02 / 04(2)$ & $-1(2)$ & $-1(2)$ & $-2(1)$ & $-2(1)$ & $-2(1)$ & $-3(1)$ & $-3(1)$ & $-4(1)$ & $-3(1)$ & $-4(1)$ \\
\hline \multirow[t]{2}{*}{$04 / 15$} & $-(-)$ & $08 / 05(7)$ & $0(8)$ & $-3(3)$ & $-3(3)$ & $-4(3)$ & $-4(3)$ & $-5(3)$ & $-6(3)$ & $-6(2)$ & $-7(2)$ \\
\hline & \multicolumn{11}{|c|}{ V7 development stage } \\
\hline $08 / 15$ & $01 / 10(6)$ & $-4(5)$ & $-4(5)$ & $-7(5)$ & $-7(5)$ & $-10(4)$ & $-9(5)$ & $-12(4)$ & $-12(4)$ & $-14(4)$ & $-15(4)$ \\
\hline $09 / 15$ & $27 / 10(3)$ & $-4(3)$ & $-4(4)$ & $-7(3)$ & $-7(3)$ & $-9(3)$ & $-9(3)$ & $-11(3)$ & $-12(3)$ & $-13(3)$ & $-14(3)$ \\
\hline $10 / 15$ & 19/11(3) & $-2(3)$ & $-3(3)$ & $-4(3)$ & $-5(3)$ & $-6(2)$ & $-7(2)$ & $-8(2)$ & $-8(2)$ & $-9(2)$ & $-10(2)$ \\
\hline $11 / 15$ & $14 / 12(2)$ & $-1(2)$ & $-2(2)$ & $-3(2)$ & $-3(2)$ & $-3(1)$ & $-4(2)$ & $-4(1)$ & $-5(1)$ & $-4(1)$ & $-6(1)$ \\
\hline $12 / 15$ & 10/01(2) & $-1(1)$ & $-1(1)$ & $-1(1)$ & $-2(1)$ & $-2(1)$ & $-3(1)$ & $-2(1)$ & $-3(1)$ & $-2(1)$ & $-4(1)$ \\
\hline $01 / 15$ & $09 / 02(1)$ & $-1(1)$ & $-1(1)$ & $-1(1)$ & $-2(1)$ & $-2(1)$ & $-3(1)$ & $-2(1)$ & $-3(1)$ & $-2(1)$ & $-3(1)$ \\
\hline $02 / 15$ & $13 / 03(2)$ & $-1(2)$ & $-1(2)$ & $-2(1)$ & $-2(1)$ & $-3(1)$ & $-3(1)$ & $-3(1)$ & $-4(1)$ & $-3(1)$ & $-5(1)$ \\
\hline 03/15 & $14 / 04(2)$ & $-2(2)$ & $-2(2)$ & $-3(2)$ & $-4(2)$ & $-5(2)$ & $-5(2)$ & $-6(2)$ & $-7(1)$ & $-6(1)$ & $-8(1)$ \\
\hline \multirow[t]{2}{*}{$04 / 15$} & $-(-)$ & $24 / 05(6)$ & $0(6)$ & $-7(4)$ & $-6(4)$ & $-8(4)$ & $-8(4)$ & $-10(4)$ & $-10(4)$ & $-12(3)$ & $-13(3)$ \\
\hline & \multicolumn{11}{|c|}{ V11 development stage } \\
\hline 08/15 & $20 / 10(5)$ & $-5(5)$ & $-5(5)$ & $-9(5)$ & $-9(5)$ & $-13(4)$ & $-12(5)$ & $-16(4)$ & $-16(5)$ & $-19(4)$ & $-19(4)$ \\
\hline $09 / 15$ & $13 / 11(4)$ & $-5(4)$ & $-5(4)$ & $-9(4)$ & $-9(4)$ & $-12(3)$ & $-12(3)$ & $-15(3)$ & $-15(3)$ & $-17(3)$ & $-18(3)$ \\
\hline $10 / 15$ & $03 / 12(4)$ & $-3(3)$ & $-3(3)$ & $-5(3)$ & $-5(3)$ & $-7(3)$ & $-8(3)$ & $-9(2)$ & $-10(2)$ & $-10(2)$ & $-12(2)$ \\
\hline $11 / 15$ & $27 / 12(2)$ & $-2(2)$ & $-2(2)$ & $-3(2)$ & $-4(2)$ & $-4(2)$ & $-6(2)$ & $-5(2)$ & $-7(1)$ & $-5(2)$ & $-8(1)$ \\
\hline $12 / 15$ & $23 / 01(2)$ & $-2(1)$ & $-2(1)$ & $-3(1)$ & $-4(1)$ & $-3(1)$ & $-5(1)$ & $-3(1)$ & $-5(1)$ & $-3(2)$ & $-6(1)$ \\
\hline $01 / 15$ & $22 / 02(2)$ & $-2(1)$ & $-2(1)$ & $-3(1)$ & $-4(1)$ & $-3(1)$ & $-5(1)$ & $-4(1)$ & $-5(1)$ & $-3(2)$ & $-6(1)$ \\
\hline $02 / 15$ & 27/03(3) & $-2(2)$ & $-2(2)$ & $-3(2)$ & $-4(2)$ & $-5(2)$ & $-6(2)$ & $-5(2)$ & $-7(1)$ & $-5(2)$ & $-8(1)$ \\
\hline $03 / 15$ & $01 / 05(5)$ & $-3(4)$ & $-4(4)$ & $-6(3)$ & $-6(3)$ & $-8(3)$ & $-9(3)$ & $-10(2)$ & $-11(2)$ & $-11(2)$ & $-13(2)$ \\
\hline $04 / 15$ & $-(-)$ & $15 / 06(1)$ & $-1(2)$ & $-9(5)$ & $-7(6)$ & $-11(5)$ & $-11(6)$ & $-15(5)$ & $-15(5)$ & $-18(4)$ & $-19(4)$ \\
\hline
\end{tabular}


in the early (08/15 and 09/15) and late (04/15) emergence dates. Compared to current climate, V4, V7 and V11 were simulated as earlier as 10, 15 and 19 days, respectively. These results indicate changes in field management practices in maize, if climate changes in the future.

\section{Conclusions}

1. The risk of frost for very early and very late emergence dates of maize decreases in warmer climates, leading to a lengthening in the calendar year for growing maize.

2. Climate scenarios with elevated temperatures lead to a decrease in the duration of the leaf emergence phase period in maize.

3. Asymmetric increases in air temperature result in shorter duration of leaf emergence period than symmetric increases, indicating that warmer nights accelerate vegetative development in maize.

\section{Acknowledgments}

To Conselho Nacional de Desenvolvimento Científico e Tecnológico and to Coordenação de Aperfeiçoamento de Pessoal de Nível Superior for the scholarships.

\section{References}

BYJESH, K.; KUMAR, S.N.; AGGARWAL, P.K. Simulating impacts, potential adaptation and vulnerability of maize to climate change in India. Mitigation and Adaptation Strategies for Global Change, v.15, p.413-431, 2010.

EMBRAPA TRIGO. Milho BRS Missões. Available at: < http:// www.cnpt.embrapa.br/culturas/milho/cultivares/c_mimissoes. htm>. Acessed on: May 17, 2005.

FORSTHOFER, E.L.; SILVA, P.R.F. da; ARGENTA, G.; STRIEDER, M.L.; SUHRE, E.; RAMBO, L. Desenvolvimento fenológico e agronômico de três híbridos de milho em três épocas de semeadura. Ciência Rural, v.34, p.1341-1348, 2004.

GARDNER, B.R.; BLAD, B.L.; WATTS, D.G. Plant and air temperatures in differentially-irrigated corn. Agricultural Meteorology, v.25, p.207-217, 1981.

HELDWEIN, A.B.; ESTEFANEL, V.; MANFRON, P.A.; BURIOL, G.A.; SCHNEIDER, F.M. Análise das temperaturas mínimas do ar registradas em Santa Maria, RS. I- Estimativa das temperaturas mínimas do ar a $5 \mathrm{~cm}$ da superfície do solo relvado e do solo desnudo. Revista do Centro de Ciências Rurais, v.18, p.3-14, 1988.

INTERGOVERNMENTAL PANEL ON CLIMATE CHANGE. Climate change 2007: the physical science basis: contribution of Working Group I to the Fourth Assessment Report of the Intergovernmental Panel on Climate Change. Cambridge: Cambridge University Press, 2007. 996p.

JONES, P.G.; THORNTON, P.K. The potential impacts of climate change on maize production in Africa and Latin America in 2055. Global Environmental Change, v.13, p.51-59, 2003.

KEER, R.A. Millennium's hottest decade retains its title, for now. Science, v.307, p.828-829, 2005.

KIM, S.H.; GITZ, D.C.; SICHER, R.C.; BAKER, J.T.; TIMLIN, D.J.; REDDY, V.R. Temperature dependence of growth, development, and photosynthesis in maize under elevated $\mathrm{CO}_{2}$. Environmental and Experimental Botany, v.61, p.224-236, 2007.

LAGO, I.; STRECK, N.A.; ALBERTO, C.M.; OLIVEIRA, F.B.; PAULA, G.M. de. Impact of increasing mean air temperature on the development of rice and red rice. Pesquisa Agropecuária Brasileira, v.43, p.1441-1448, 2008.

LEVITT, J. Responses of plants to environmental stresses. New York: Academic, 1972. 697p.

MANN, M.E.; BRADLEY, R.S.; HUGHES, M.K. Global-scale temperature patterns and climate forcing over the past six centuries. Nature, v.392, p.779-787, 1998.

MANN, M.E.; BRADLEY, R.S.; HUGHES, M.K. Northern Hemisphere temperatures during the past millennium: inferences, uncertainties, and limitations. Geophysical Research Letters, v.26, p.759-762, 1999.

MANN, M.E.; ZHANG, Z.H.; HUGHES, M.K.; BRADLEY, R.S.; MILLER, S.K.;RUTHERFORD, S.;NI, F.Proxy-basedreconstructions of hemispheric and global surface temperature variations over the past two millennia. Proceedings of the National Academy of the United States of America, v.105, p.13252-13257, 2008.

MARQUES, J.R.Q.; STEINMETZ, S.; DINIZ, G.; SIQUEIRA, O.J.; WREGE, M.S.; HERTER, F.; REISSER JUNIOR, C. Aumento da temperatura mínima do ar no Rio Grande do Sul, sua relação com o aquecimento global e possível impactos no arroz irrigado. In: CONGRESSO BRASILEIRO DE ARROZ IRRIGADO, 4.; REUNIÃO DA CULTURA DO ARROZ IRRIGADO, 26., 2005, Santa Maria. Anais. Santa Maria: Sociedade Sul-Brasileira de Arroz Irrigado, 2005. v.1, p.224-226.

MOLION, L.C.B. Aquecimento global: mitos e verdades. In: CONGRESSO BRASILEIRO DE ARROZ IRRIGADO, 6., 2009, Porto Alegre. Estresses e sustentabilidade: desafios para a lavoura arrozeira: anais. Porto Alegre: Sociedade Sul-Brasileira de Arroz Irrigado, 2009. p.526-539.

PENG, S.; HUANG, J.; SHEEHY, J.E.; LAZA, R.C.; VISPERAS, R.M.;ZHONG, X.; CENTENEO, G.S.; KHUSH, G.S.; CASSMAN, K.G. Rice yields decline with higher night temperature from global warming. Proceedings of the National Academy of Sciences of the United States of America, v.101, p.9971-9975, 2004.

REUNIÃO TÉCNICA ANUAL DO MILHO, 53.; REUNIÃO TÉCNICA ANUAL DO SORGO, 36., 2008, Pelotas. Indicações 
técnicas para o cultivo de milho e sorgo no Rio Grande do Sul: 2008/2009. Pelotas: Embrapa Clima Temperado, 2008. 169p.

RITCHIE, S.W.; HANWAY, J.J.; BENSON, G.O. How a corn plant develops. Ames: Iowa State University of Science and Technology, 1997. 21p. (Special report, 48).

SEMENOV, M.A.; BROOKS, R.J.; BARROW, E.M.; RICHARDSON, C.W. Comparison of the WGEN and LARS-WG stochastic weather generators for diverse climates. Climate Research, v.10, p.95-107, 1998.

STEINMETZ,S.;PINHEIRO, M.J.;FERREIRA, J.S.A.;DEIBLER, A.N. Aumento da temperatura mínima do ar na região de Pelotas, sua relação com o aquecimento global e possíveis conseqüências para o arroz irrigado no Rio Grande do Sul. In: CONGRESSO BRASILEIRO DE AGROMETEOROLOGIA, 14., 2005, Campinas. Agrometeorologia, agroclimatologia e agronegócio: anais. Campinas: Sociedade Brasileira de Agrometeorologia, 2005. 1 CD-ROM.

STRECK, N.A.; ALBERTO, C.M. Estudo numérico do impacto da mudança climática sobre o rendimento de trigo, soja e milho. Pesquisa Agropecuária Brasileira, v.41, p.1351-1359, $2006 \mathrm{a}$.

STRECK, N.A.; ALBERTO, C.M. Simulação do impacto da mudança climática sobre a água disponível do solo em agroecossistemas de trigo, soja e milho em Santa Maria, RS. Ciência Rural, v.36, p.424-433, 2006 b.

STRECK, N.A.; GABRIEL, L.F.; SAMBORANHA, F.K.; LAGO, I.; SCHWANTES, A.P.; SCHONS, A. Comparing two versions of a non-linear model for simulating leaf number and developmental stages in maize based on air temperature. Ciência Rural, v.39, p.642-648, 2009 .

STRECK, N.A.; LAGO, I.; ALBERTO, C.M.; BISOGNIN, D.A. Simulação do desenvolvimento da batata cultivar Asterix em cinco cenários de mudanças climáticas em Santa Maria, RS. Bragantia, v.65, p.693-702, 2006.

TRAVASSO, M.I.; MAGRIN, G.O.; RODRIGUEZ, G.R.; SOLMAN, S.; NUÑEZ, M. Climate change impacts on regional maize yields and possible adaptation measures in Argentina. International Journal of Global Warming, v.1, p.201-213, 2009.

UNITED STATES DEPARTMENT OF AGRICULTURE. Foreign Agricultural Service. Production, supply and distribution online: custom query. 2010. Available at: $<$ http://www.fas.usda. gov/psdonline/psdQuery.aspx>. Accessed on: 17 May 2010.

WANG, E.; ENGEL, T. Simulation of phenological development of wheat crops. Agricultural Systems, v.58, p.1-24, 1998.

Received on August 1', 2010 and accepted on October 4, 2010 